\title{
An Analysis of Polymorphism Lymphotoxin Alpha +252 A>G in South Indian Breast Cancer Patients
}

\author{
Karuvaje THRIVENI ${ }^{1}$, Anisha RAJU ${ }^{1}$, Girija RAMASWAMY' ${ }^{1}$, S. Krishna MURTHY ${ }^{2}$, \\ Rekha V. KUMAR ${ }^{3}$
}

\author{
${ }^{1}$ Kidwai Cancer Institute, Department of Biochemistry \\ ${ }^{2}$ Kidwai Cancer Institute, Department of Surgical Oncology \\ ${ }^{3}$ Kidwai Cancer Institute, Department of Pathology, Karnataka, INDIA
}

\begin{abstract}
Cytokine tumor necrosis factor contributes to a wide range of functions like inflammation, immunomodulatory and apoptotic activities. Our aim was to investigate the association of plasma levels of lymphotoxin alpha (LTA) with polymorphism rs909253 at $+252 \mathrm{~A}>\mathrm{G}$ in primary invasive breast cancer(BC) patients. A total of 146 patients and 150 age matched healthy controls were included in the study. Genotyping was carried out by polymerase chain reaction and restriction fragment length polymorphism. Plasma levels were estimated by The MILLIPLEX® MAP Human Cytokine / Chemokine Panel magnetic bead kits. Data was statistically analysed by R software version 3.3.1. Plasma levels of LTA was significantly increased in cases when compared to controls. However, when levels was analyzed according to polymorphic subtypes there was no significant difference. The polymorphism was in consistent with the Hardy Weinberg(HW) equilibrium, showing $X^{2}$ values of $2.3(p=0.13)$ and 2.02( $\left.p=0.15\right)$ for cases and controls respectively. Odds ratio $(\mathrm{OR})$ indicated that polymorphism was not significantly associated with breast cancer. Plasma levels of LTA were not altered due to polymorphism in patients and controls. Tumors of high- grade and hormone receptor negative cases showed higher frequency of the $G$ allele, indicating that $G$ allele patients may have worse prognosis. This study suggests that $L T A+252 A>G$ gene polymorphism is not a prominent risk factor for $\mathrm{BC}$.
\end{abstract}

Keywords: Breast cancer, Inflammation, Polymorphism, Tumor necrosis factor

ÖZET

Güney Hindistanda Meme Kanseri Hastalarında Bir Polimorfizm Lenfotoksin Alfa +252 A>G Analizi

Sitokin tümör nekrozis faktörü, inflamasyon, immünomodülatör ve apoptotik aktiviteler gibi geniş bir fonksiyon yelpazesine katkıda bulunur. Amacımız, primer invaziv meme kanserli hastalarda, plazma lenfotoksin alfa (LTA) düzeyinin +252A>G'de polimorfizm rs909253 ile ilişkisini araştırmaktı. Çalışmaya toplam 146 hasta ve yaş-uyarlı 150 sağıklı kontrol alındı. Genotipleme, polimeraz zincir reaksiyonu ve kısıllama fragmanı uzunluğu polimorfizmiyle gerçekleştirildi. Plazma seviyeleri, MILLIPLEX® MAP İnsan Sitokin / Chemokine Panel manyetik boncuk kitleri tarafından tahmin edilmiștir. Verilerin istatistiksel analizi R software version 3.3.1. ile yapılmıştır. Plazma LTA düzeyleri, kontrol grubuna göre anlamlı düzeyde arttı. Ancak, düzeyler polimorfik alt tiplere göre analiz edildiğinde anlamlı fark yoktu. Polimorfizm, vakalar ve kontroller için X2 değerleri sırasıyla $2.3(p=0.13)$ ve $2.02(p=0.15)$ idi ve Hardy Weinberg (HW) dengesiyle tutarlıydı. Odds ratio (OR), polimorfizmin meme kanseri ile anlamlı bir șekilde ilişkili olmadığını gösterdi. Plazma LTA seviyeleri, hastalar ve kontrollerde polimorfizm nedeniyle değişmedi. Yüksek grade'li ve hormon reseptör negatif olguların tümörlerinde $G$ allel frekansı daha yüksekti, bu da G allel hastalarıın daha kötü prognoza sahip olabileceğini göstermektedir. Bu çalışma, LTA +252A>G gen polimorfizminin meme kanseri için belirgin bir risk faktörü olmadığını göstermektedir.

Anahtar Kelimeler: Meme kanseri, İnflamasyon, Polimorfizm, Tümör nekrozis faktör 


\section{INTRODUCTION}

Breast cancer is highly heterogeneous and the leading cause of cancer mortality among women in developing countries. Inflammation is one of the characteristics of a tumor which may play a role in metastasis. The earliest cytokine produced in inflammatory processes is tumor necrosis factor (TNF), which generates a cytokine cascade and helps to produce interleukin-1, interleukin- 6 and other mediators, along with TNF itself. ${ }^{1,2}$ As a key regulator, tumor necrosis factor plays an important role in the progression of breast cancer.

TNF induces a cascade of other inflammatory cytokines, chemokines and growth factors. Chronic production of TNF enhances angiogenesis, causes interaction between stromal cells and malignant cells in the extracellular matrix effecting tumor promotion. Elevated levels of TNF are found in stromal inflammatory cells in breast cancer. ${ }^{3}$ Leek et al. showed that chronic inflammation in the tumor microenvironment with high levels of TNF can contribute to the growth and progression of breast tumors. ${ }^{4}$ Altered expression levels of TNF has been found when there was a common genetic variation in chromosome $6 \mathrm{p} 21 .^{5,6}$ Genetic variants may contribute to cancer predisposition.

Tumor necrosis factor $\beta$ (TNF- $\beta$ ), also known as lymphotoxin alpha(LTA) is a pro inflammatory cytokine secreted by lymphocytes and is structurally identical to TNF $\alpha .^{7}$ The two factors have $30 \%$ identity and 55\% homology in amino acid sequences and are recognized by the same widely distributed cellular receptors sharing many of their functions . ${ }^{7}$ The LTA gene is adjacent to the TNF- $\alpha$ gene and both are located within a $7 \mathrm{~kb}$ locus in the major histocompatibility complex (MHC). ${ }^{7}$ Since it is adjacent to MHC, the TNF gene is highly polymorphic and genetic variation may lead to increased production of cytokine LTA ${ }^{8,9}$, helping tumor development and progression.

Polymorphism $\mathrm{A}>\mathrm{G}$ located at position +252 within the first intron of the TNF $\beta$ / LTA gene affects the expression of both genes and concentration of circulating $\operatorname{TNF}(\alpha$ and $\beta)$ proteins in plasma. ${ }^{10}$ The less common allele $(252 \mathrm{G})$ has been correlated with a higher TNF $\beta$ expression, both at the gene and circulating levels. ${ }^{11}$ Plasma levels of LTA are increased when there is a genetic variation found at the first intron of the gene at nucleotide position $+252 \mathrm{~A}>\mathrm{G}$ of chromosome 6 . This polymorphism replaces A by $\mathrm{G}$, causing allelic forms like $+252 \mathrm{GG}$ and $+252 \mathrm{GA}$, creating Nco I restriction sites. The polymorphism is conserved and located within a phorbol ester-responsive DNA element(TRE) family. Significantly, elevated levels of plasma LTA are due to $+252 \mathrm{G}$ allele by phyto hemagglutininstimulated peripheral blood mononuclear cells via LTA gene transcription. ${ }^{11}$ LTA (A252G) polymorphism has been associated with an increased risk of breast, esophageal, gastric and colorectal cancer. $^{12,13}$

The objective of this study was to ascertain whether the systemic release of LTA/TNF - $\beta$ in plasma was associated with gene polymorphism of $+252 \mathrm{~A}>\mathrm{G}$ (rs 909253) and to also analyse polymorphism with breast cancer susceptibility.

\section{PATIENTS and METHODS}

This prospective case control study design was approved by the Institutional Scientific Review Board and Medical Ethics Committee. Informed consent was taken from every individual who participated in the study at the time of blood collection. Patients registered between June 2014 and December 2014 at Kidwai Memorial Institute of Oncology were selected for the study. The subjects under study included 296 women, comprised of 146 primary invasive ductal carcinoma of breast and 150 healthy age and menses matched ( \pm 4 years) controls who were without active infection, autoimmune disease or steroid treatment. All the women belonged to the same ethnic group -South Indian population.

Patients with invasive ductal carcinoma cases as confirmed by the pathologist were selected. Patients' age, menopausal status, stage, lymph node status, pathological grade, hormone receptor and HER-2/neu status were recorded from case files. Blood sample were collected in $5 \mathrm{ml}$ heparin vacutainers by venepuncture prior to treatment. The plasma was separated by centrifugation and stored at $-80^{\circ} \mathrm{C}$ for LTA levels. The MILLIPLEX® MAP Human Cytokine / Chemokine Panel magnetic bead kits were used to measure the levels of LTA. The stock standard concentration was $10000 \mathrm{pg} / \mathrm{ml}$ 
which was serially diluted to plot a standard curve. Luminex reader recorded the analyte concentration based on the standard curve.

\section{Genotyping}

The leukocytes were separated and stored at $-20^{\circ} \mathrm{C}$. Genomic DNA was extracted from the leukocytes by the conventional phenol chloroform method. The concentration of genomic DNA(gDNA) was measured using Eppendorf biospectrometer. Polymerase chain reaction restriction fragment length polymorphism (PCR- RFLP) method was used to detect the polymorphism using previously published protocols with minor modifications. ${ }^{14}$

The PCR amplicon of 368 base pairs was obtained after carrying out reactions in $30 \mu 1$ reaction mixture. The sequence of forward primer was 5' CTCCTGCACCTGCTGCCTGGATC and reverse primer sequence was 5'GAAGAGACGTTCAGGTGGTGTCA14. The reaction mixture contained $1 \mu \mathrm{M}$ forward and the reverse primers (Sigma), 200 $\mu \mathrm{M}$ of dNTP, Taq DNA polymerase $1 \mathrm{x}$ buffer with $1.5 \mathrm{mM} \mathrm{MgCl}, 2.5$ units Taq Polymerase(Sigma) and $200 \mathrm{ng} / \mu \mathrm{L}$ of gDNA as template. After initial denaturation at $95^{\circ} \mathrm{C}$ for 10 minutes, PCR reactions were performed for 31 cycles as heat denaturation $\left(96^{\circ} \mathrm{C}\right.$ for $\left.1 \mathrm{~min}\right)$, annealing $\left(65^{\circ} \mathrm{C}\right.$ for $\left.1 \mathrm{~min}\right)$, and extension $\left(72^{\circ} \mathrm{C}\right.$ for $\left.2 \mathrm{~min}\right)$ followed by final extension of $72^{\circ} \mathrm{C}$ for 5 minutes. The amplification process was carried out in the thermal cycler S1000 Bio Rad Laboratories, USA.

A transition substitution from A to $\mathrm{G}$ at LTA +252 region creates restriction site for Nco I enzyme. The PCR amplicons were digested by $2 \mathrm{U}$ of restriction enzyme Nco I (New England Biolabs) followed by $2 \%$ agarose gel electrophoresis. The PCR amplicon of 368bp with LTA +252AA wild type allele was not cleaved. However, amplicon of homozygous mutant with GG allele was cleaved to produce $133 \mathrm{bp}$ and $235 \mathrm{bp}$ fragments. The presence of both non cleaved $368 \mathrm{bp}$ and cleaved fragments in a sample was considered as heterozygous GA allele.

\section{Sequence Analysis}

Genotypes were verified by direct sequencing of PCR products in three different samples. The PCR product of $+252 \mathrm{~A}>\mathrm{G}$ polymorphism with an amplicon of 368bp was validated by sequence analysis showing a polymorphism $A>G$ at 133 region in the amplicon which could be cleaved into two fragments of $133 \mathrm{bp}$ and $235 \mathrm{bp}$.

\section{Statistical Analysis}

R-statistics software version 3.3.1 was used to perform all statistical analyses. Numerical summaries tool was used to find mean and standard deviation(SD) for continuous variables. Mann -Whitney U test was used to find tests of significance value. The frequencies of alleles and genotype of cases were compared to control group. Two way contingency table and Chi square analysis tested the association between the genetic polymorphism by calculating an odds ratios (OR) with a $95 \%$ confidence interval (CI). OR value was used to find the strength of risk association with the prognostic factors. A p-value less than 0.05 was considered statistically significant. Court lab calculator calculated the $\chi^{2}$ value to estimate whether the genotype distributions were within the HW equilibrium ( $\mathrm{p}>0.05)$.

\section{RESULTS}

The demographic features of the cases are represented in Table 1. A total of eight prognostic parameters were considered for the stratification analysisage at diagnosis, menopausal status, TNM staging, lymph node metastases, pathological grading, ER, PR and HER-2-neu status. Patients' ages ranged from 25- 80 years with a mean age of 49 years. Of the 146 cases $29 \%$ were premenopausal and $71 \%$ were postmenopausal, $61 \%$ of cases were node positive, $56 \%$ were in late stages, $62 \%$ were in high grade. Hormone receptor status showed that $63 \%$ were ER positive, $55 \%$ were PR positive and $26 \%$ were HER-2/neu positive cases.

Plasma expression of LTA: Levels of LTA were significantly high in BCs than in the control samples (Table 2). Mean and SD were $3.22 \pm 1.1 \mathrm{pg} / \mathrm{ml}$ and $8.29 \pm 6.44 \mathrm{pg} / \mathrm{ml}(\mathrm{p}<0.001)$ for controls and cases respectively. However, when allelic variants (A and $G$ ) were considered, there was no significant differences in plasma values in controls $(\mathrm{p}=$ $0.821)$ and patients $(\mathrm{p}=0.26)$. 
International Journal of Hematology and Oncology

\begin{tabular}{|lc|}
\hline \multicolumn{2}{|l|}{ Table 1. Demographic features of breast cancer patients } \\
\hline Prognostic factors & No (\%) (n= 146) \\
\hline Age (years) (mean $49 \pm 12$ ranges & $25-80)$ \\
$\quad<50$ years & $76(52 \%)$ \\
$\quad>50$ years & $70(48 \%)$ \\
Menopausal state & \\
$\quad$ Premenopausal & $43(29 \%)$ \\
Postmenopausal & $103(71 \%)$ \\
Node & \\
Positive & $89(61 \%)$ \\
Negative & $57(39 \%)$ \\
Stage & \\
Early & $64(44 \%)$ \\
Late & $82(56 \%)$ \\
Grade & \\
Low & $55(38 \%)$ \\
High & $91(62 \%)$ \\
Estrogen receptor & \\
Positive & $92(63 \%)$ \\
Negative & $54(37 \%)$ \\
Progesterone Receptor & \\
Positive & \\
Negative & $60(55 \%)$ \\
HER-2/neu & \\
Positive & \\
Negative & \\
&
\end{tabular}

\section{LTA +252 polymorphism and BC}

The genotypic distribution of SNP was in concordant with the HW equilibrium with the $\mathrm{p}$ value of $>$ 0.05 (Table 3). The minor allelic frequency of LTA $+252 \mathrm{G}$ was 0.24 in the cases and 0.22 in the controls. Among 146 cases, the genotypic frequency for homozygous wild type AA was $60 \%$, heterozy-

\begin{tabular}{|c|c|c|}
\hline & $\begin{array}{l}\text { LTA values }(\mathrm{pg} / \mathrm{ml}) \\
(\text { Mean } \pm \text { SD) }\end{array}$ & Significance \\
\hline Control (150) & $3.22+1.1$ & \\
\hline Cases (146) & $8.29+6.44$ & $<0.001^{*}$ \\
\hline \multicolumn{3}{|l|}{ Control (150) } \\
\hline A (95) & $3.17+1.33$ & \\
\hline G (55) & $3.47+1.22$ & 0.821 \\
\hline \multicolumn{3}{|l|}{ Cases (146) } \\
\hline$A(87)$ & $8.75+6.5$ & \\
\hline G (59) & $7.82+6.3$ & 0.26 \\
\hline
\end{tabular}

gous GA was $32 \%$ and mutant GG was $8 \%$. The values for control group was $\mathrm{AA}=63 \%, \mathrm{GA}=30 \%$ and $\mathrm{GG}=7 \%$ respectively.

LTA +252 polymorphism and clinicopathological features of BC: The genotypic frequencies in cases with each prognostic factors are summarized in Figure 1. Patients with high grade and hormone receptor negative tumors showed around $50 \%$ of $\mathrm{G}$ allele frequencies. To assess the strength of association between prognostic factors and polymorphism (AA vs GA+GG) OR with $95 \%$ confident interval (95\% CI) was calculated.

Table 3. Genotype and allelic frequencies of LTA $+252 A>G$ polymorphism in controls and cases

$+252 A>G \quad$ Cases $(n=146) \quad$ Controls $(n=150)$

\begin{tabular}{lllll}
\hline & Observed & Expected & Observed & $\begin{array}{l}\text { Expected } \\
\text { AA }\end{array}$ \\
GA & $87(60 \%)$ & $83.6(57 \%)$ & $95(63 \%)$ & $92(61 \%)$ \\
GG & $47(32 \%)$ & $53.7(37 \%)$ & $45(30 \%)$ & $50.9(34 \%)$ \\
Hardy-Weinberg equilibrium & $12(8 \%)$ & $8.6(6 \%)$ & $10(7 \%)$ & $7.0(5 \%)$ \\
Variance of allele frequency & $X^{2}=2.3 ; p=0.13$ & & $X^{2}=2.02 ; \mathrm{p}=0.15$ \\
A Allele & 0.24 & & 0.22 \\
G Allele & $221(76 \%)$ & & $235(78 \%)$ \\
Inference & $71(24 \%)$ & $65(22 \%)$ & \\
& Consistent with HWE & & Consistent with HWE
\end{tabular}




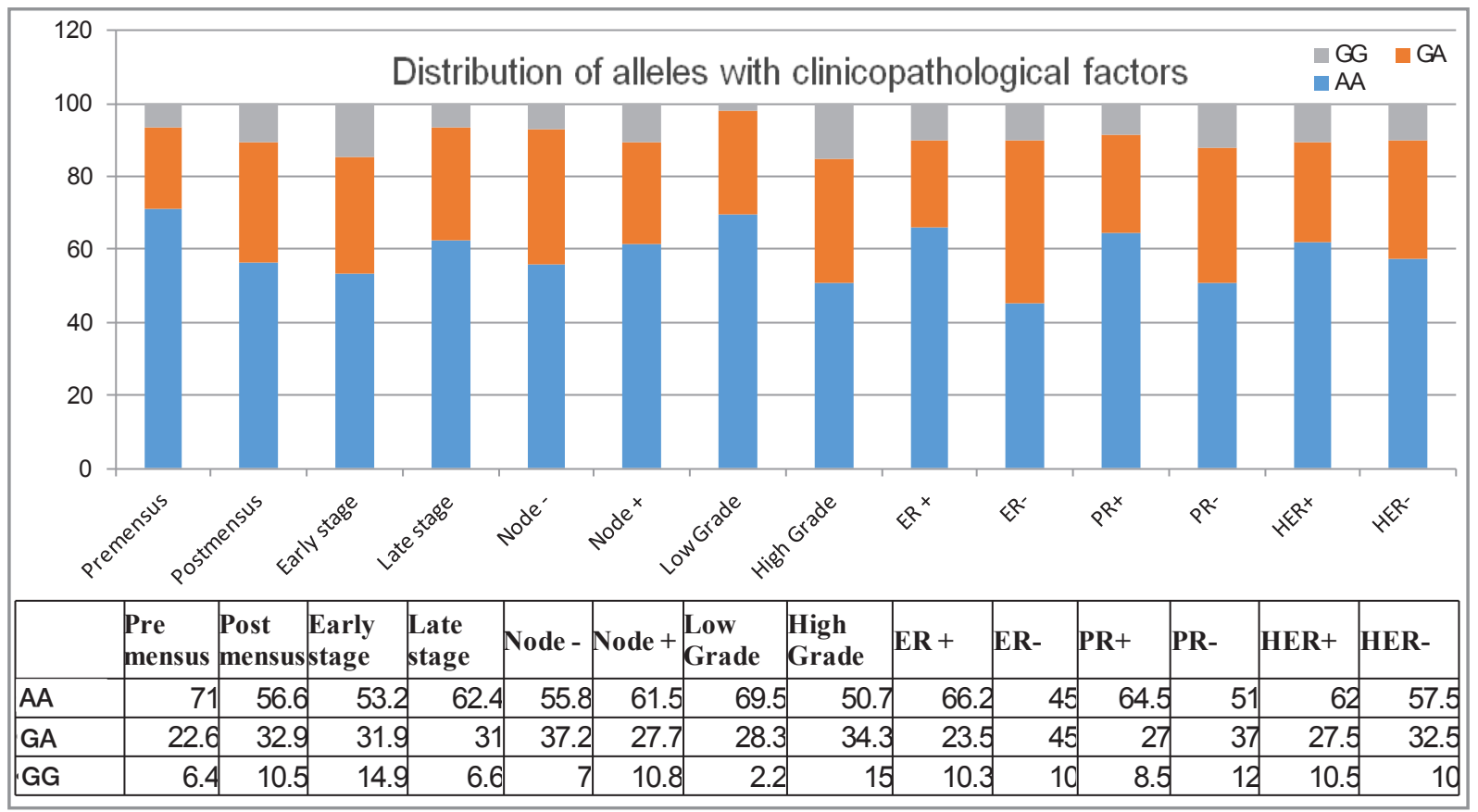

Figure 1. Genotypic frequencies of LTA gene polymorphism in cases

AA: Wild type major allele; GA: Heterozygous; GG: Mutant minor allele

As presented in Table IV, an association was not found between LTA +252 polymorphism $(\mathrm{OR}=$ $1.27,95 \% \mathrm{CI}=0.66-2.46, \mathrm{p}=0.43$ ) and breast cancer risk. From the updated review of literature, an analysis of LTA +252 polymorphism from seven different studies with various geographical and ethnicity were compared. Table 4 shows the detailed characteristics of the analysis. We have considered risk association and polymorphism in genotype AA vs $\mathrm{GA}+\mathrm{GG}$ since $\mathrm{G}$ allele was recessive and few cases of GG genotype were present. In two North Indian studies, strong association was observed in LTA +252 polymorphism with BC and OR was of $1.43(1.09-1.87)$ and $2.38(1.17-4.85)$ with a p value less than 0.05 . Two Korean studies also show an association with an OR of 1.16 and 1.62.

\section{DISCUSSION}

Cancer is a multifactorial disease, wherein complex interactions of genetic, epigenetic and environmental factors occur. ${ }^{15}$ One of the important factors in the pathogenesis of cancer is inflammation. Immune system deregulation is a crucial risk factor for cancer progression. Homeostasis in the microenvironment is lost during inflammation. In- flammatory cytokines play a vital role in different stages of tumor development and progression to metastasis. The genetic polymorphism of LTA at $+252 \mathrm{~A}>\mathrm{G}$ allele may influence the susceptibility to breast cancer. In the process of tumorigenesis and the activation of dormant tumor cells, LTA G allele plays an important role. ${ }^{16}$

This proinflammatory cytokine secreted into the microenvironment, may promote progression of disease and distant metastasis. Low levels of plasma LTA implicate lesser inflammation and lower immune responses. ${ }^{17}$ Some of the literature have shown that LTA $+252 \mathrm{~A}$ allele is associated with lesser synthesis of LTA cytokines as compared to the $\mathrm{G}$ allele11. On the contrary, the phenotype data from Wichelow et al. ${ }^{18}$ showed that those with LTA GG genotype secreted significantly lower levels of LTA than those with A-allele. Another study showed that polymorphism may alter individual susceptibility to breast cancer risk in postmenopausal women. ${ }^{19}$ The present study does not show an association of plasma levels with gene polymorphism.

We compared our findings with the existing literature of LTA polymorphism in human breast cancer. The data summarized in relation to breast cancer 


\begin{tabular}{|c|c|c|c|c|c|}
\hline & Genotype & Case (\%) & Control (\%) & Odds ratio $(95 \% \mathrm{Cl})$ & P for trend \\
\hline Current study & $\mathrm{GA}+\mathrm{GG}$ & 59 (23.9) & $52(14.1)$ & & \\
\hline South India & AA & $87(35.4)$ & $98(26.6)$ & $1.27(0.66-2.46)$ & 0.43 \\
\hline Karakus N (2011) & $\mathrm{GA}+\mathrm{GG}$ & $101(24.7)$ & $116(28.4)$ & & \\
\hline Turkish & AA & $103(25.2)$ & $88(21.5)$ & $0.74(0.50-1.1)$ & 0.082 \\
\hline Pooja S (2011) & $G A+G G$ & $193(21.3)$ & $145(16.1)$ & & \\
\hline North India & AA & $272(30.3)$ & $292(32.3)$ & $1.43(1.09-1.87)$ & $0.006^{*}$ \\
\hline Kohaar I (2009) & $G A+G G$ & $24(12.7)$ & $58(30.5)$ & & \\
\hline North India & AA & $16(8.4)$ & $92(48.4)$ & $2.38(1.17-4.85)$ & $0.025^{\star}$ \\
\hline Gaudet MM( 2007) & $\mathrm{GA}+\mathrm{GG}$ & $1654(29.2)$ & $1478(26.1)$ & & \\
\hline US, Poland & AA & $1384(24.5)$ & $1138(20.2)$ & $0.92(0.83-1.02)$ & 0.40 \\
\hline Kamali Sarves tani (2005) & $\mathrm{GA}+\mathrm{GG}$ & $120(26.9)$ & $112(25.1)$ & & \\
\hline Iran & AA & 99 (22.2) & $115(25.8)$ & $1.25(0.86-1.81)$ & 0.29 \\
\hline Lee KM (2005) & $\mathrm{GA}+\mathrm{GG}$ & $375(35.7)$ & $321(30.6)$ & & \\
\hline Korea & AA & $178(16.9)$ & $176(16.8)$ & $1.16(0.88-1.49)$ & $0.03^{*}$ \\
\hline Park KS (2002) & $\mathrm{GA}+\mathrm{GG}$ & $62(21.7)$ & $102(35.8)$ & & \\
\hline Korea & $A A$ & $33(11.7)$ & 88 (30.8) & $1.62(0.97-2.7)$ & $0.04^{\star}$ \\
\hline
\end{tabular}

susceptibility was controversial and evasive. As shown in Table 4, paradoxical results were observed in different populations. Polymorphism rs 909253 was observed to be a significantly associated risk factor for breast cancer with odds ratio of 1.62 and 1.16 respectively in two Korean studies. ${ }^{16,19}$ Similarly, in two North India studies, polymorphism was significantly associated with breast cancer susceptibility with OR of 1.43 and $2.38 .^{20,21}$ Our study, comprising more of south India women may show ethnic variation. The lack of significant association of rs 909253 SNP is consistent with the previous studies from the US and Iran. ${ }^{22,23}$ Conversely, a Turkish study on breast cancer showed more frequent LTA $+252 \mathrm{GG}$ genotypes in cases when compared to controls. ${ }^{24}$ The impact of a "set of polymorphisms" study in identifying linkage disequilibrium and haplotype associated functional outcomes on gene expression is higher than single SNP analysis. ${ }^{25}$

There is no data available for simultaneous analysis of plasma levels of LTA and genetic analysis on LTA polymorphism in breast cancer. Our study implicates that plasma levels of the cytokine do not increase in the variant LTA $252 \mathrm{G}$ allele patients due to single nucleotide polymorphism. Control group and $\mathrm{BC}$ patients showed no significant differences between wild type major A allele and minor $\mathrm{G}$ allele. This indicates that polymorphism rs 909253 is not a marker of causative risk factor. There was no association between the prognostic factors and functional polymorphism. However, patients with mutant allele $\mathrm{G}$ had higher grade and hormone receptor negative $\mathrm{BCs}$ indicating that they may be more prone to have aggressive diseases.

As a confounding factor, genetic variation helps in the evaluation of cancer susceptibility mechanisms. Ethnic background and geographical variations reflect the complexity of the genetic heritage of risk allele. Two studies from North Indian population showed that this polymorphism was associated with breast cancer risk. This regional variation patterns may reflect collective diverse factors like varying presence of carcinogens in the environment and lifestyle. The differences in results may be plausible due to different geographical regions and ethnic variations in India. Our data adds to the body of literature regarding risk of rs 909253 polymorphism in breast cancer by showing no association in South India women population. 
The major limitations of the study was sample size. Better statistical results may be achieved with larger numbers. However, lack of reproducibility of results is attributable to low allele frequency in current ethnic groups and not due to inadequately populated. Secondly, more than two polymorphism analysis may help to show the linkage disequilibrium. Follow up clinical data of these patients would have been given better predictor value which was missing in many cases. But the advantage of this study was concurrent analysis of plasma LTA value with LTA polymorphism.

\section{Acknowledgement:}

Authors thank Rajiv Gandhi University of Health Sciences, Karnataka, India for funding the project.

\section{REFERENCES}

1. Bazzoni F, Beutler B. The tumor necrosis factor ligand and receptor families. N Engl J Med 334: 1717-1725, 1996.

2. Barnes PJ, Karin M. Nuclear factor-kappa B: A pivotal transcription factor in chronic inflammatory diseases. $N$ Engl J Med 336: 1066-1071, 1996.

3. Balkwill F, Tumor necrosis factor or tumor promoting factor? Cytokine Growth Factor Rev 13: 135-141, 2002.

4. Leek RD, Landers R, Fox SB, et al. Association of tumor necrosis factor alpha and its receptor with thymidine phosphorylase expression in invasive breast carcinoma. Br J Cancer 77: 2246-2251, 1998.

5. Negoro K, Kinouchi Y, Hiwatashi N, et al. Crohns disease is associated with novel polymorphism in the 5' flanking region of the tumor necrosis factor gene. Gastroenterology 117: 1062-1068, 1999.

6. Westendorp RG, Langermans JA, Huizinga TW, et al. Genetic influence on cytokine production in meningococcal diseases. Lancet 349: 1912-1913, 1997.

7. Aggarwal BB, Kohr WJ, Hass PE, et al. Human tumor necrosis factor: Production purification and characterization. J Biol Chem 260: 2345-2354, 1985.

8. Belfer I, Buzas B, Hipp H, et al. Haplotype structure of inflammatory cytokines gene ( IL1B,IL6 and TNF/LTA) In US Caucasians and African Americans. Genes 5: 505-512, 2004.

9. Posch PE, Cruz I, Bradshaw D, et al. Novel polymorphism and definition of promoter alleles of tumor necrosis factor and lymphotoxin alpha loci: inclusion in HLA haplotypes. Genes Immun 4: 547-258, 2003.
10. Pociot F, Briant L, Jongeneeel CV, et al. Association of tumor necrosis factor (TNF) and class II major histocompatibility complex alleles with the secretion of TNF- $\alpha$ and TNF- $\beta$ by human mononuclear cells: a possible link to insulin-dependent diabetes mellitus. Eur J Immunol 23: 224-231, 1993.

11. Messer G, Spengler U, Jung MC, et al. Polymorphic structure of the tumor necrosis factor (TNF) locus: an Ncol polymorphism in the first intron of the human TNF-beta gene correlates with a variant amino acid in position 26 and a reduced level of TNF-beta production. J Exp Med 173: 209-219, 1991.

12. Azmy IA, Balasubramanian SP, Wilson AG, et al. Role of tumor necrosis factor gene polymorphism (-308 and -238) in breast cancer susceptibility and severity. Breast Cancer Res 6: 395-400, 2004.

13. Saito S, Kasai Y, Nomoto S, et al. Polymorphism of tumor necrosis factor in esophageal, gastric or colorectal carcinoma. Hepatogastroenterol 48: 468-470, 2001.

14. Warzocha K, Ribeiro P, Bienvenu J, et al. Genetic polymorphism in the tumor necrosis factor locus influence Non-Hodgkin's lymphoma outcome. Blood 91: 3574-3581, 1998.

15. Shih CM, Lee YL, Chiou HL, et al. Association of TNF-alpha polymorphism with susceptibility to and severity of non-small cell lung cancer. Lung Cancer 52:15-20, 2006.

16. Park KS, Mok JW, Ko HE, et al. Polymorphisms of tumour necrosis factors $A$ and $B$ in breast cancer. Eur $\mathrm{J}$ Immunogenet 29: 7-10, 2002.

17. Landskron G, De la Fuente M, Thuwajit $P$, et al. Chronic inflammation and cytokines in the tumor microenvironment. J Immunol Res 149185, 2014. doi: 10.1155/2014/149185.

18. Whichelow CE, Hitman GA, Raafat I, et al. The effect of TNF beta gene polymorphism on TNF-alpha and -beta secretion levels in patients with insulin-dependent diabetes mellitus and healthy controls. Eur J Immunogenet 23: 425-435, 1996.

19. Lee KM, Park SK, Hamajima N, et al. Genetic polymorphisms of TGF-beta1 \& TNF-beta and breast cancer risk. Breast Cancer Res Treat 90: 149-155, 2005.

20. Kohaar I, Tiwari P, Kumar R, et al. Association of single nucleotide polymorphisms (SNPs) in TNF-LTA locus with breast cancer risk in Indian population. Breast Cancer Res Treat 114: 347-355, 2009.

21. Pooja S, Francis A, Bid HK, et al. Role of ethnic variations in TNF alpha and TNF-beta polymorphisms and risk of breast cancer in India. Breast Cancer Res Treat 126: 739-747, 2011.

22. Gaudet MM, Egan KM, Lissowska J, et al. Genetic variation in tumor necrosis factor and lymphotoxin-alpha (TNF-LTA) and breast cancer risk. Hum Genet 121: 483-490, 2007.

23. Kamali-Sarvestani E, Merat A, Talei AR. Polymorphism in the genes of alpha and beta tumor necrosis factors (TNF-alpha and TNF-beta) and gamma interferon (IFN-gamma) among Iranian women with breast cancer. Cancer Lett 223: 113$119,2005$. 
International Journal of Hematology and Oncology

24. Karakus N, Kara N, Ulusoy AN, et al. Tumor necrosis factor alpha and beta and interferon gamma gene polymorphisms in Turkish breast cancer patients. DNA Cell Biol 30: 371-377, 2011.

25. Drysdale CM, McGraw DW, Stack CB, et al. Complex promoter and coding region beta 2-adrenergic receptor haplotypes alter receptor expression and predict in vivo responsiveness. Proc Natl Acad Sci USA 97: 10483-10488, 2000.

\section{Correspondence:}

Dr. Karuvaje THRIVENI

Kidwai Cancer Institute, Department of Biochemistry

Marigowda Road,

Bangalore-560029

KARNATAKA INDIA

Tel: $\quad+918026094072$

Fax: +918026560723

GSM: +919449346490

e-mail: thrivenibhat@yahoo.com 